\title{
IX. Red List of Lampreys and Marine Fishes of the Wadden Sea*
}

\author{
CONTRIBUTORS: \\ Denmark: S. Berg, C. Krog, B. Muus, J. Nielsen \\ Germany: R. Fricke “, R. Berghahn, Th. Neudecker \\ The Netherlands: W. J. Wolff
}

\section{INTRODUCTION}

During the compilation of the red list on marine fishes and lampreys of the Wadden Sea area, several problems in the definition of criteria have to be faced which are important for the classification of the taxa. One major problem was the concept of 'taxa regularly reproducing within the area' on which the categories were based. For most of the North Sea species, populations in the sense of reproductive units comprise large circulation systems (like the complete North Sea or, for the eel Anguilla anguilla, even the whole North Atlantic), as the species disperse over long distances by large-scale migration or planktonic eggs and larvae.

The only taxon living exclusively in the Wadden Sea area is Coregonus lavaretus oxyrhinchus. Other fish and lamprey species living in the Wadden Sea area are usually not isolated reproductive units, but part of larger populations. Therefore, for Wadden Sea species, the term "population" is not used in the sense of isolated reproductive unit. The presence of a species in the Wadden Sea area is treated as a population if the Wadden Sea is an important part of the reproductive unit in which a decline of the population size may be a threat for the whole reproductive unit. Therefore, anadromous, catadromous, and other migrants are considered, even if they mainly reproduce outside the Wadden Sea area.

\section{Delimitation of the survey area}

For the present trilateral Red List of lampreys and marine fishes, the $20 \mathrm{~m}$ depth line is used as the seaward boundary.

* This list forms part of the Report on the RED LISTS OF BIOTOPES, FLORA AND FAUNA OF THE TRILATERAL WADDEN SEA AREA. For basic information concerning, for example, function of these lists, species taken into account, structure of the lists and abbreviations used, see also the general introduction to the Red Lists.

* Author of the introductory text.

(C) Biologische Anstalt Helgoland, Hamburg und Bundesamt für Naturschutz, Bonn 


\section{Threats and Conservation}

Considering general threats for the Wadden Sea fishes and lampreys, marine and non-marine causes are distinguished. In the Wadden Sea, the major threat for several species is an intensive fishery for industrial and food purposes (e.g. Nijssen \& de Groot, 1987). Most of the fisheries target species were considered over-fished and their populations showed a steady decline, but they were not classified as threatened due to their reproductional $r$-strategies including a possible rapid recruitment of stocks. Fisheries and stock sizes are under control of the EU, and regulations should enable the stocks to recover when fishing effort is reduced.

However, the North Sea is one of the most heavily fished areas in the world, and the fisheries cause a destabilization of the ecosystem. Therefore, conservation efforts should concentrate on non-target species, which are caught as by-catch or die in the discard of commercial fisheries. Several of these non-target species have slow growth and low recruitment rates.

An example for a threatened non-target species is the Sturgeon Acipenser sturio, immature specimens of which used to live in the Wadden Sea for 10-15 years before being able to spawn. This species is extinct in the entire Wadden Sea area, but still found in 3 rivers in southwestern Europe, but its status there is critical. The large and slowly reproducing rays Dasyatis pastinaca and Raja clavata are believed to have declined because of intensive trawling (de Vooys et al., 1991).

Several anadromous and catadromous migrants like Petromyzon marinus, Lampetra fluviatilis, Acipenser sturio, Alosa alosa, Alosa fallax, Salmo salar, and Salmo trutta trutta are threatened by degradation of rivers, especially by construction of dams and weirs hampering the migration of the species. The eutrophication of running waters leads to a degradation of the gravel areas necessary as spawning sites for these species by covering sandy areas with mud.

An additional threat to some Wadden Sea species is the loss of their habitat. Threatened by the destruction of seagrass beds are the pipefishes Syngnathus acus, S. typhle, and Entelurus aequoreus, and the stickleback Spinachia spinachia (e.g. Redeke, 1941; Nijssen \& de Groot, 1987).

Further threats include the enormous influx of waste water, heavy metals and organochlorines through the rivers into the Wadden Sea area, and the eutrophication of the marine habitats.

\section{Summary}

In the Wadden Sea areas of Denmark, Germany and The Netherlands, a total of 162 fish and lamprey species is known. 72 of these species are migrants entering the area occasionally; the total number of resident species in the Wadden Sea area is 90.

In the Wadden Sea, in total, 20 species of fish and lamprey species are threatened in at least one subregion. Of these, 19 species are threatened in the entire area and are therefore placed on the trilateral Red List. 2 species of the listed fish and lamprey species are (probably) extinct in the entire Wadden Sea area. The status of 5 species of fish and lamprey species is critical, 5 species are (probably) endangered, the status of 6 is vulnerable and of 1 species susceptible. 
For about 16 rare species which may also be threatened, data were not sufficient to estimate past and present population sizes. The contributors to the list would like to encourage researchers to intensify work on the ecology and the present population sizes of these rare Wadden Sea species (see Fricke et al., 1995).

\section{REFERENCES}

Fricke, R., Berghahn, R. \& Th. Neudecker, 1995. Rote Liste der Rundmäuler und Meeresfische des deutschen Wattenmeer- und Nordseebereichs (mit Anh.: nicht gefährdete Arten). - SchrReihe Landschaftspfl. Natursch. 44, $101-112$.

Nijssen, H. \& Groot, S. J. de, 1987. De Vissen van Nederland. K. Ned. Natuurhist. Ver., Utrecht, 224 pp.

Redeke, H., 1941. Pisces (Cyclostomi-Euichthyes). - Fauna Ned. 10, 1 - 331.

Vooys, C. G. N. de, Witte, J. IJ., Dapper, R., Meer, J. M. van der \& H. W. van der Veer, 1991. Lange termijn veranderingen in zeldzame vissorten op het Nederlandse continentaal plat van de Nordzee. - NIOZ-rapp. 1991-6, 81 pp.

\section{RED LIST OF LAMPREYS AND MARINE FISHES OF THE WADDEN SEA}

EX - Extinct:

Acipenser sturio

(?) Trachinus draco

CR - Critical:

Alosa alosa

Coregonus lavaretus oxyrhinchus

$=$ C. oxyrhinchus

Dasyatis pastinaca

Raja clavata

Salmo salar

EN - Endangered:

(?) Echiichthys vipera

Lampetra fluviatilis

Petromyzon marinus

Salmo trutta trutta

(?) Syngnathus typhle
VU - Vulnerable:

Alosa fallax

Eutrigla gurnardus

Liparis liparis

Liparis montagui

Spinachia spinachia

Syngnathus acus

SU - Susceptible:

(?) Atherina presbyter

- Question-marks indicate that in one of the subregions the status of threat is uncertain. 


\section{LIST OF THREATENED LAMPREYS AND MARINE FISHES OF THE WADDEN SEA}

\begin{tabular}{|c|c|c|c|c|c|c|}
\hline & & \multirow[t]{2}{*}{$\begin{array}{l}\text { Red List } \\
\text { (trilateral) }\end{array}$} & \multirow{2}{*}{ Threats } & \multicolumn{3}{|c|}{$\begin{array}{l}\text { Status of threat in the subre- } \\
\text { gions of the Wadden Sea Area }\end{array}$} \\
\hline \multicolumn{2}{|l|}{. } & & & NL & $\mathrm{Nds} / \mathrm{SH}$ & DK \\
\hline \multicolumn{7}{|c|}{ Agnatha } \\
\hline $\begin{array}{l}\text { Lampetra fluviatilis } \\
\text { (Linnaeus, 1758) }\end{array}$ & $\begin{array}{l}\text { Rivierprik } \\
\text { Flußneunauge } \\
\text { Flodlampret }\end{array}$ & EN & $\begin{array}{l}\text { WAT, POL, } \\
\text { EUT, EXL? }\end{array}$ & Vu & EN & VU \\
\hline $\begin{array}{l}\text { Petromyzon marinus } \\
\text { Linnaeus, } 1758\end{array}$ & $\begin{array}{l}\text { Zeeprik } \\
\text { Meerneunauge } \\
\text { Havlampret }\end{array}$ & EN & $\begin{array}{l}\text { WAT, POL, } \\
\text { EUT, EXL? }\end{array}$ & VU & EN & VU \\
\hline \multicolumn{7}{|c|}{ Chondrichthyes } \\
\hline $\begin{array}{l}\text { Dasyatis pastinaca } \\
\text { (Linnaeus, } 1758 \text { ) }\end{array}$ & $\begin{array}{l}\text { Pijlstaartrog } \\
\text { Stechrochen } \\
\text { Pilrokke }\end{array}$ & CR & EXL & CR & EX & $(*)$ \\
\hline Raja clavata Linnaeus, 1758 & $\begin{array}{l}\text { Stekelrog } \\
\text { Nagelrochen } \\
\text { Sømrokke }\end{array}$ & CR & EXL & EN & EX & * \\
\hline \multicolumn{7}{|c|}{ Osteichthyes } \\
\hline $\begin{array}{l}\text { Acipenser sturio } \\
\text { Linnaeus, } 1758\end{array}$ & $\begin{array}{l}\text { Steur } \\
\text { Stör } \\
\text { Stør }\end{array}$ & EX & $\begin{array}{l}\text { WAT, POL, } \\
\text { EXL }\end{array}$ & EX & EX & $\begin{array}{c}\text { EX } \\
\text { (since } \\
1942)\end{array}$ \\
\hline $\begin{array}{l}\text { Alosa alosa } \\
\text { (Linnaeus, 1758) }\end{array}$ & $\begin{array}{l}\text { Elft } \\
\text { Alse, Maifisch } \\
\text { Majsild }\end{array}$ & CR & $\begin{array}{l}\text { WAT, POL, } \\
\text { EUT }\end{array}$ & CR & CR & CR \\
\hline $\begin{array}{l}\text { Alosa fallax } \\
\text { (Lacepede, 1803) }\end{array}$ & $\begin{array}{l}\text { Fint } \\
\text { Finte } \\
\text { Stavsild }\end{array}$ & VU & $\begin{array}{l}\text { WAT, POL, } \\
\text { EUT }\end{array}$ & VU & VU & VU \\
\hline $\begin{array}{l}\text { Atherina presbyter } \\
\text { Cuvier } 1829\end{array}$ & $\begin{array}{l}\text { Koornaarvis } \\
\text { Ährenfisch } \\
\text { Stribefisk }\end{array}$ & SU? & WAT & SU & - & $\left({ }^{\star}\right)$ \\
\hline $\begin{array}{l}\text { Coregonus lavaretus oxy- } \\
\text { rhinchus (Linnaeus, 1758) } \\
=\text { C.oxyrhinchus }\end{array}$ & $\begin{array}{l}\text { Houting } \\
\text { Schnäpel } \\
\text { Snæbel }\end{array}$ & CRJEX & $\begin{array}{l}\text { WAT, POL, } \\
\text { EUT, EXL? }\end{array}$ & EX & EX & SU* \\
\hline $\begin{array}{l}\text { Echiichthys vipera } \\
\text { (Cuvier, 1829) }\end{array}$ & $\begin{array}{l}\text { Kleine Pieterman } \\
\text { KI. Petermännchen } \\
\text { Lille fjæsing }\end{array}$ & EN? & & EN & - & $\left({ }^{\star}\right)$ \\
\hline
\end{tabular}

- According to Danish scientists and authorities, the species reintroduced into the Danish Wadden Sea area is Coregonus oxyrhinchus, identical to C. lavaretus oxyrhynchus. The German experts do not agree to this, and a final agreement among the scientists must be left to the future. 


\begin{tabular}{|c|c|c|c|c|c|c|}
\hline & & \multirow[t]{2}{*}{$\begin{array}{l}\text { Red List } \\
\text { (trilateral) }\end{array}$} & \multirow{2}{*}{ Threats } & \multicolumn{3}{|c|}{$\begin{array}{l}\text { Status of threat in the subre- } \\
\text { gions of the Wadden Sea Area }\end{array}$} \\
\hline & & & & NL & $\mathrm{Nds} / \mathrm{SH}$ & DK \\
\hline $\begin{array}{l}\text { Entelurus aequoreus } \\
\text { (Linnaeus, 1758) }\end{array}$ & $\begin{array}{l}\text { Adderzeenaald } \\
\text { Große Schlangennadel } \\
\text { Snippe }\end{array}$ & * & $H A B$ & * & SU & * \\
\hline $\begin{array}{l}\text { Eutrigla gurnardus } \\
\text { (Linnaeus, 1758) }\end{array}$ & $\begin{array}{l}\text { Grauwe poon } \\
\text { Grauer Knurrhahn } \\
\text { Gră knurhane }\end{array}$ & Vu & EXL & * & Vu & $?$ \\
\hline $\begin{array}{l}\text { Liparis liparis } \\
\text { (Linnaeus, 1758) }\end{array}$ & $\begin{array}{l}\text { Slakdolf } \\
\text { Großer Scheibenbauch } \\
\text { Finnebræmmet ringbug }\end{array}$ & Vu & & * & VU & $?$ \\
\hline $\begin{array}{l}\text { Liparis montagui } \\
\text { (Donovan, 1804) }\end{array}$ & $\begin{array}{l}\text { Kleine slakdolf } \\
\text { Kleiner Scheibenbauch } \\
\text { Særfinnet ringbug } \\
\end{array}$ & Vu & & - & VU & $?$ \\
\hline $\begin{array}{l}\text { Salmo salar } \\
\text { Limnaeus. } 1758\end{array}$ & $\begin{array}{l}\text { Zalm } \\
\text { Lachs } \\
\text { Laks } \\
\end{array}$ & CR & $\begin{array}{l}\text { WAT, EUT, } \\
\text { EXL, POL? }\end{array}$ & EX & $C R$ & $E X^{\circ}$ \\
\hline $\begin{array}{l}\text { Salmo trutta trutta } \\
\text { Linnaeus, } 1758\end{array}$ & $\begin{array}{l}\text { Zeeforel } \\
\text { Meerforelle } \\
\text { Ørred } \\
\end{array}$ & EN & $\begin{array}{l}\text { WAT, EUT? } \\
\text { EXL, POL? }\end{array}$ & SU & EN & VU \\
\hline $\begin{array}{l}\text { Spinachia spinachia } \\
\text { (Linnaeus 1758) }\end{array}$ & $\begin{array}{l}\text { Zeestekelbaars } \\
\text { Seestichling } \\
\text { Tangsnarre } \\
\end{array}$ & Vu & $\mathrm{HAB}$ & EX & VU & * \\
\hline $\begin{array}{l}\text { Syngnathus acus } \\
\text { Linnaeus, } 1758\end{array}$ & $\begin{array}{l}\text { Grote Zeenaald } \\
\text { Große Seenadel } \\
\text { Stor tangnål } \\
\end{array}$ & Vu & $\mathrm{HAB}$ & * & EN & $?$ \\
\hline $\begin{array}{l}\text { Syngnathus typhle } \\
\text { Linnaeus, } 1758\end{array}$ & $\begin{array}{l}\text { Trompetterzeenaald } \\
\text { Grasnadel } \\
\text { Almindelig tangnåi }\end{array}$ & EN? & $\mathrm{HAB}$ & EX & EN? & * \\
\hline $\begin{array}{l}\text { Trachinus draco } \\
\text { Linnaeus, } 1758\end{array}$ & $\begin{array}{l}\text { Grote Pieterman } \\
\text { Großes Petermännchen } \\
\text { Fjæsing }\end{array}$ & EX? & EXL? & EX & EX & $\left(^{*}\right)$ \\
\hline
\end{tabular}

- The salmon stocks now populating the Danish rivers and streams originate from strains bred in fish farms, and they are genetically different from the original stocks.

Status of threat:

EX $=$ Extinct $; \mathbf{C R}=$ Critical; $\mathbf{E N}=$ Endangered $; \mathbf{V U}=$ Vulnerable $; \mathbf{S U}=$ Susceptible $;{ }^{*}=$ not endan gered $_{i} ?=$ status of endangerment is not exactly known; $*=$ species does not occur $; \cdot(?)=$ species probably does not occur; $\left({ }^{*}\right)=$ it is unknown if or if not this species occurs.

Threats:

$\mathrm{AFF}=$ afforestation $; \mathrm{AGR}=$ agriculture $; \mathrm{CLI}=$ climatic change $; \mathrm{DIS}=$ disturbance $; \mathrm{EUT}=$ eutrophication; $E X L=$ exploitation of living resources; $E X M=$ mineral exploitation $; F O R=$ forestry; $H A B=$ loss of habitat; $\mathrm{PAR}=$ parasites; $\mathrm{POL}=$ pollution $;$ WAT $=$ water regulation .

For more detailed descriptions see the general introduction to the Red Lists. 